\title{
Salt marsh stabilization affects algal primary producers at the marsh edge
}

\author{
Mary I. O'Connor • Christy R. Violin • \\ Andrea Anton • Laura M. Ladwig • \\ Michael F. Piehler
}

Received: 4 January 2010/ Accepted: 8 December 2010/Published online: 8 January 2011

(C) The Author(s) 2011. This article is published with open access at Springerlink.com

\begin{abstract}
As sea level rise and human activities erode coastal wetlands, managers rebuild or preserve wetlands that can perform the ecosystem services of a natural system. One increasingly common mitigation activity is the construction of rock sills in the low marsh zone to stabilize marsh elevation. Sills dramatically alter the physical structure of marshes by changing elevation, adding hard substrate and potentially altering the spatial structure of benthic algal communities in and adjacent to the low marsh. We documented differences in benthic algal abundance at the seaward marsh edge in silled and unsilled marshes in North Carolina. We found that sills were associated with reduced standing stocks of benthic algal
\end{abstract}

Electronic supplementary material The online version of this article (doi:10.1007/s11273-010-9206-y) contains supplementary material, which is available to authorized users.

M. I. O’Connor $(\bowtie)$

National Center for Ecological Analysis and Synthesis (NCEAS), 735 State Street, Suite 300, Santa Barbara, CA 93101, USA

e-mail: oconnor@zoology.ubc.ca

C. R. Violin

Department of Biology, University of North CarolinaChapel Hill, Chapel Hill, NC 27599, USA

M. I. O’Connor · A. Anton

Curriculum for the Environment and Ecology,

University of North Carolina-Chapel Hill, Chapel Hill,

NC 27599, USA primary production and reduced macroalgal taxonomic richness, and this difference was driven primarily by differences in macroalgal abundance. We experimentally tested the effect of macroalgal abundance on cordgrass (Spartina alterniflora) growth in the low zone of an unmanipulated marsh, and found that macroalgal removal had no effect on final cordgrass abundance. Our study suggests that salt marsh management through the construction of sills in low marsh zones impacts benthic primary production in the low marsh zone, but that benthic algal production does not affect cordgrass growth over a growing season.

Keywords Salt marsh - North Carolina $\cdot$ Benthic algae $\cdot$ Macroalgae $\cdot$ Shoreline stabilization

\author{
L. M. Ladwig \\ Department of Biology, University of New Mexico, \\ Albuquerque, NM 87131, USA \\ M. F. Piehler \\ Institute of Marine Sciences, Morehead City, \\ NC 28577, USA \\ Present Address: \\ M. I. O'Connor \\ Biodiversity Research Centre, University of British \\ Columbia (UBC), Vancouver, BC V6T 1Z4, Canada
}




\section{Introduction}

In the mid-Atlantic region of the U.S., the rate of sea level rise over the past century $(2.4-4.4 \mathrm{~mm} / \mathrm{year})$ exceeded the global average rate of $1.7 \mathrm{~mm} / \mathrm{year}$, affecting the elevation, function and distribution of shoreline habitats as well as restoration projects (Nixon 1980; Warren and Niering 1993; Donnelly and Bertness 2001; CCSP 2009). An increasingly common management response to sea level rise is to construct hard structures to protect shrinking shoreline habitats (Benoit et al. 2007). These projects attempt to accommodate tidal marshes while also stabilizing shorelines, but the full effects of installed structures on the structure and function of coastal ecosystems are not well understood.

One shoreline erosion management method is the construction of a 'living shoreline', which is built behind a hard substrate such as a rock sill installed seaward of a marsh (Hershner et al. 2006; Benoit et al. 2007). The area behind the sill is then backfilled with sediment and marsh cordgrass (Spartina alterniflora) is planted. The extent to which such restored and stabilized marshes achieve ecosystem function of natural marshes is beginning to be evaluated (Currin et al. 2008). Some ecosystem properties such as marsh grass density and fish abundance return fairly quickly to levels similar to natural marshes, but accretion rates and other biogeochemical processes such as soil nitrogen storage may take longer (Piehler et al. 1998; Currin et al. 2008). One of the most important metrics of ecosystem function is standing stocks of primary producers (benthic micro- and macroalgae and marsh grass), though effects of sills on benthic algal primary producers have yet to be examined.

In the low marsh zone and the subtidal adjacent sand and mud flats, the main primary producer functional groups are benthic macro- and micro-algae and marsh grass. Benthic algal primary producers contribute to subtidal and marsh carbon and nutrient cycling (Osgood and Zieman 1993; Valiela et al. 1997; Piehler et al. 1998; Boyer and Fong 2005; Sundback and McGlathery 2005); primary production by benthic micro-algae in this zone typically ranges from 50 to $300 \mathrm{mg} \mathrm{C} \mathrm{m}^{-2}$ year $^{-1}$, which is of the same magnitude as phytoplankton production in estuarine waters, and both macro- and micro-algae contribute significantly to total primary production in shallow estuarine waters (Sundback and McGlathery 2005). Benthic algae are vulnerable to changes in marsh elevation, hydrology and associated soil properties, and changes in the location and abundance of macroalgae could have cascading effects on secondary productivity (Hauxwell et al. 1998) and nutrient supply to low marsh plants (Boyer and Fong 2005).

Despite the importance of benthic primary producers, the consequences of disruption or enhancement of algal growth in low marsh zones for cordgrass growth and abundance in North Carolina estuaries have not been explored. We conducted field surveys and a manipulative experiment to address two questions in North Carolina coastal marshes: (1) Has artificial shoreline stabilization altered the abundance of benthic primary producers in the low marsh zone? (2) What are the implications of changing macroalgal abundance for cordgrass growth, flowering and microalgal abundance in these low marsh zones?

\section{Methods}

\section{Study system}

Bogue Sound is a temperate, shallow sound with very short residence time and virtually no river inputs. Similar to other well-flushed coastal sounds, nutrient levels remain relatively low in spite of recent development of the watershed (O'Connor et al. 2009). There is some evidence that current nitrate concentrations exceed levels observed several decades ago (Micheli et al. 2008), suggesting some deterioration in water quality, but the lack of longterm records leaves this trend inconclusive. In response to rising sea levels, rock sills have been installed in Bogue Sound marshes since 1998 (Currin et al. 2008).

We studied primary producer abundance at two sites with stabilization projects (hereafter, 'silled marshes') adjacent to shorelines with no stabilization projects (hereafter, 'natural marshes'). The sills we studied were constructed by installing large rocks parallel to the shoreline in the low marsh zone. Sills are approximately $2 \mathrm{~m}$ wide at the base, and rise about $1 \mathrm{~m}$ above the sand. When constructed, the area behind the sills is frequently backfilled with sediment and planted with marsh grass. 
The sills we studied were built within the last decade: the Pine Knoll Shores (PKS, at $34.7011^{\circ} \mathrm{N}-$ $\left.76.8319^{\circ} \mathrm{W}\right)$ project was finished in 2001 and Harker's Island (HI, $\left.34.7117^{\circ} \mathrm{N}-76.5661^{\circ} \mathrm{W}\right)$ in 2004. The Pine Knoll Shores sill is located on the northern side of Bogue Banks. The 100-m sill was installed by The North Carolina Coastal Federation, and was planted with $S$. alterniflora and $S$. patens behind the sill to supplement the significant existing vegetation (Currin et al. 2008). The Harkers Island Sill is $125 \mathrm{~m}$ and was planted with $S$. alterniflora (Bonnie Bendell, NC Division of Coastal Management-Personal communication). The marshes in this study have wave energy exposure representative of fringing marshes in coastal North Carolina (Mark Fonseca, NOAA NOS Center for Coastal Fisheries and Habitat Research-Personal communication). At both marshes, the subtidal edge of Spartina occurs within $1 \mathrm{~m}$ of the sill. We studied natural marshes adjacent to the sills (within $500 \mathrm{~m}$ ) at each site, and know of no differences in disturbance history of the two locations prior to installation of the sills. It is important to note that some natural marshes likely have been restored in some capacity, and are not old, unperturbed marshes (Zheng et al. 2004), although we do not know the detailed history of each marsh. The comparison between these and silled marshes is informative, because sills are a dramatic perturbation, and a much more recent one.

\section{Surveys}

We quantified benthic algal abundance and composition on natural and silled marshes bimonthly between January 2007 and April 2008. In each survey, macroalgae and marsh plants were identified and percent cover was estimated in $0.5 \mathrm{~m}^{2}$ quadrats at the low marsh edge. Visual percent cover estimates have been shown to be a repeatable and efficient sampling method (Dethier et al. 1993). At each site on each sampling date, we surveyed three replicate transects. We made visual estimates of percent cover of algae, seagrass, and marsh plants. We identified macroaglae to the lowest taxonomic level possible in the field (typically, genus) based on morphological and color traits. We measured microalgal abundance in the upper $0.5 \mathrm{~cm}$ of sediment using chlorophyll a as a proxy for biomass (Welschmeyer non-acidification method). Total benthic algal standing stocks were estimated by summing an estimate of macroalgal biomass converted from the percent cover measurements with microalgal biomass estimates.

To test the hypothesis that sills alter the abundance of macroalgae at the marsh edge, we assessed patterns of benthic algal biomass in this zone. We defined the marsh edge as the most seaward quadrat with $>10 \%$ cover $S$. alterniflora. We did not standardize the sampling by elevation but rather by proximity to $S$. alterniflora because we were interested in the potential interactions between benthic algae and the seaward edge of the marsh that may be either growing or eroding. We tested for the effect of sill, site and time on macroalgal abundance and richness, benthic microalgal abundance and $S$. alterniflora abundance at the low marsh edge with a linear mixed effects model that included sill and date as fixed factors and transects nested within sites as a random effect. We selected a Gaussian distribution based on Akaike's Information Criterion $\left(\mathrm{AIC}_{\mathrm{c}}\right)$ (Burnham and Anderson 2002) and an examination of residuals. We tested the full model and compared nested versions using $\mathrm{AIC}_{\mathrm{c}}$ to determine the importance of different factors using Eq. 1a-c:

$$
\begin{aligned}
Y_{i}= & \beta_{0}+\beta_{1} * \text { sill }+\beta_{2} * \text { time }+\beta_{3} * \text { sill } * \text { time } \\
& +\alpha_{0, S[i]}+\alpha_{1, S \mid T[i]}+\alpha_{2, S[i]} * \text { sill }+\alpha_{3, S \mid T[i]} * \text { sill } \\
& +\varepsilon_{i}
\end{aligned}
$$

$$
\left(\begin{array}{r}
\alpha_{0, S} \\
\alpha_{2, S \mid T}
\end{array}\right) \sim N\left(\left(\begin{array}{c}
\mu_{\alpha 0} \\
\mu_{\alpha 2}
\end{array}\right),\left(\begin{array}{cc}
\sigma_{\alpha 0}^{2} & \rho \sigma_{a 0} \sigma_{a 2} \\
\rho \sigma_{a 0} \sigma_{a 2} & \sigma_{\alpha 2}^{2}
\end{array}\right)\right)
$$

$$
\left(\begin{array}{r}
\alpha_{1, S} \\
\alpha_{3, S \mid T}
\end{array}\right) \sim N\left(\left(\begin{array}{l}
\mu_{\alpha 1} \\
\mu_{\alpha 3}
\end{array}\right),\left(\begin{array}{cc}
\sigma_{\alpha 1}^{2} & \rho \sigma_{a 1} \sigma_{a 3} \\
\rho \sigma_{a 1} \sigma_{a 3} & \sigma_{\alpha 3}^{2}
\end{array}\right)\right)
$$

This approach is ideally suited to our spatially structured sampling data. Equation 1a relates response variables (e.g., algal cover) to fixed effects using constants $\beta_{0}, \beta_{1}$, etc., while allowing for random effects $\left(\alpha_{0}, \alpha_{1}\right.$, etc.) among sites (S) and transects within sites (SIT) with normally distributed errors $\left(\varepsilon_{i j} \sim \mathrm{N}\left(0, \sigma^{2}\right)\right)$. Random effects vary normally, with potential covariances as described in Eq. $1 \mathrm{~b}$ and c. The comparison of nested models that vary in their inclusion of fixed and random effects is more informative than a classical ANOvA approach because it allows us to consider all alternative explanations that 
might be nearly as good as the best explanation (as determined by effect size estimates, $\mathrm{AIC}_{\mathrm{c}}$ and evidence ratios), but also to eliminate factors or their interaction if they do not explain additional variation in algal cover. In other words, comparison of nested versions of Eq. 1a allows us to determine (a) which factors modify algal cover (presence of sill, time of year), and (b) the quantitative relationship between these factors and algal responses.

Percent cover data were arcsine square-root transformed to improve normality, and data presented in figures and text are backtransformed. Algal richness data were Poisson distributed and analyzed accordingly.

\section{Experiment}

To test whether benthic macroalgae influence marsh grass growth, we manipulated macroalgal abundance in $1-\mathrm{m}^{2}$ plots of low, fringing marsh at Pine Knoll Shores, NC, USA. We tested the effects of macroalgae on S. alterniflora using two macroalgal treatments: low and high abundance. Initially, we cleared each plot of all macroalgae and installed cages to prevent large drift algae from moving in and out of plots. In low algal abundance treatments, we mimicked levels in silled marshes by removing algae by hand every 2 weeks. High algal abundance treatments were achieved by adding algae from nearby areas. Algal additions were normalized to approximately the 75th percentile of percent cover over a similar area at a natural marsh at the same time of year. The amount and composition of macroalgae in the addition treatments was reassessed and updated throughout the summer to track seasonal changes (Table 1). To estimate macroalgal abundance at the field site, algae were quantified by volume. Water was gently squeezed from the algae by hand, and algae were lightly pressed into a graduated cylinder to measure the volume. Previous sampling had shown that there is a strong correlation between algal volume and wet weight (Fig. A1). Consequently, the exact biomass and cover of algae varied during the study period to match natural patterns.

Treatments were maintained using square cages made of $5 \mathrm{~mm}$ Vexar mesh anchored to a rebar and PVC frame. Cages were anchored $10 \mathrm{~cm}$ into the sediment and stood $50 \mathrm{~cm}$ tall to exclude grazers and minimize algal removal by waves. The experiment was installed on March 17th and ended on August 31st, 2008, spanning the S. alterniflora growing season. Initial marsh grass abundance consisted exclusively of S. alterniflora. Average $( \pm \mathrm{se})$ shoot density $(31 \pm 1.5$ shoots/plot) did not differ among plots (one-way ANOVA: $\mathrm{MS}=38.917, \quad F=1.054, P=0.405)$. $S$. alterniflora shoots were young (average height $31.5 \pm$ $1.7 \mathrm{~cm}$, one-way ANOva: $\mathrm{MS}=59.434, F=1.199$, $P=0.352$ ) and predominantly vegetative propagules and so were spatially clustered into several groups.

Field cages can cause numerous artifacts that may interfere with accurate interpretation of results. To control for such artifacts, we maintained two additional treatments: a procedural control, and an open plot. In procedural controls, we set up identical cages to the manipulation treatments, and we disturbed but did not remove the macroalgae within the cage. This treatment controlled for effects of physical disturbance associated with removing algae. To control for the effects of the cage on response variables, we also observed open, unmanipulated plots at the same site. Experimental treatments were randomly ordered and

Table 1 Amount and species of macroalgae added to experimental addition treatments during experiment

\begin{tabular}{lllll}
\hline Date & Vol. $(\mathrm{ml})$ & Biomass $(\mathrm{mg})$ & \% Cover & Species \\
\hline Mar 17 & 434 & 278 & 77 & Ulva lactuca, Ectocarpus \\
Apr 23 & 380 & 241 & 69 & Ulva lactuca, Ectocarpus \\
May 14 & 160 & 96 & 31 & Ulva lactuca, Ectocarpus \\
May 22 & 470 & 303 & 84 & Ulva lactuca, Ectocarpus \\
June 11 & 227 & 139 & 43 & Gracilaria verrucosa, Ulva lactuca, Hypnea sp., Dictyota sp. \\
July 1 & 231 & 142 & 44 & Ulva lactuca, Gracilaria tickvahae, Codium fragile, Hypnea sp. \\
July 16 & 300 & 187 & 56 & Hypnea sp., G. verrucosa \\
Aug 14 & 80 & 46 & 17 & Dictyota sp. \\
\hline
\end{tabular}

Biomass (wet weight in $\mathrm{mg}$ ) and percent cover estimated using equations presented in Fig. A1 (see in Electronic supplementary material) 
installed at the low marsh edge of a fringing marsh. To estimate the elevation of experimental plots, we observed the time the center of each was inundated on the same tide.

All experimental results were analyzed with a oneway ANOVA. When necessary, as for proportional data, results were transformed for analysis and backtransformed for presentation.

\section{Sampling}

We quantified the effects of algal abundance treatments on S. alterniflora abundance and reproductive traits. S. alterniflora shoot density, height and number of flowering stems were assessed in the field by visually counting each shoot in experimental plots. Above ground biomass $\left(\mathrm{gDW} \mathrm{m}^{-2}\right)$ was estimated by collecting all shoots from each plot at the end of the experiment. S. alterniflora belowground biomass (gDW $\mathrm{m}^{-2}$ ) was sampled by collecting a $10 \times 10 \times 10 \mathrm{~cm}$ core from each plot at the end of the experiment. Shoots, roots and rhizomes were rinsed, dried and weighed. We estimated benthic microalgae by sampling using the same procedure as for the surveys.

\section{Results}

Survey results

At the seaward marsh edge, macroalgal abundance in natural marshes (mean cover $34.9 \%$ ) was four times the level observed in silled marshes (7.49\%, Fig. 1). The correlation between sills and total macroalgal cover did not vary between the two sites or over time
Fig. 1 Abundance of primary producers at seaward marsh edge of natural and silled marshes at two sites near Morehead City, NC. Backtransformed means $( \pm$ se) for total macroalgal, Spartina, microalgal abundance and macroalgal species richness at natural (filled circles) and silled (open circles) marshes at Pine Knoll Shores (panels a:d), and Harker's Island (panels e:h)
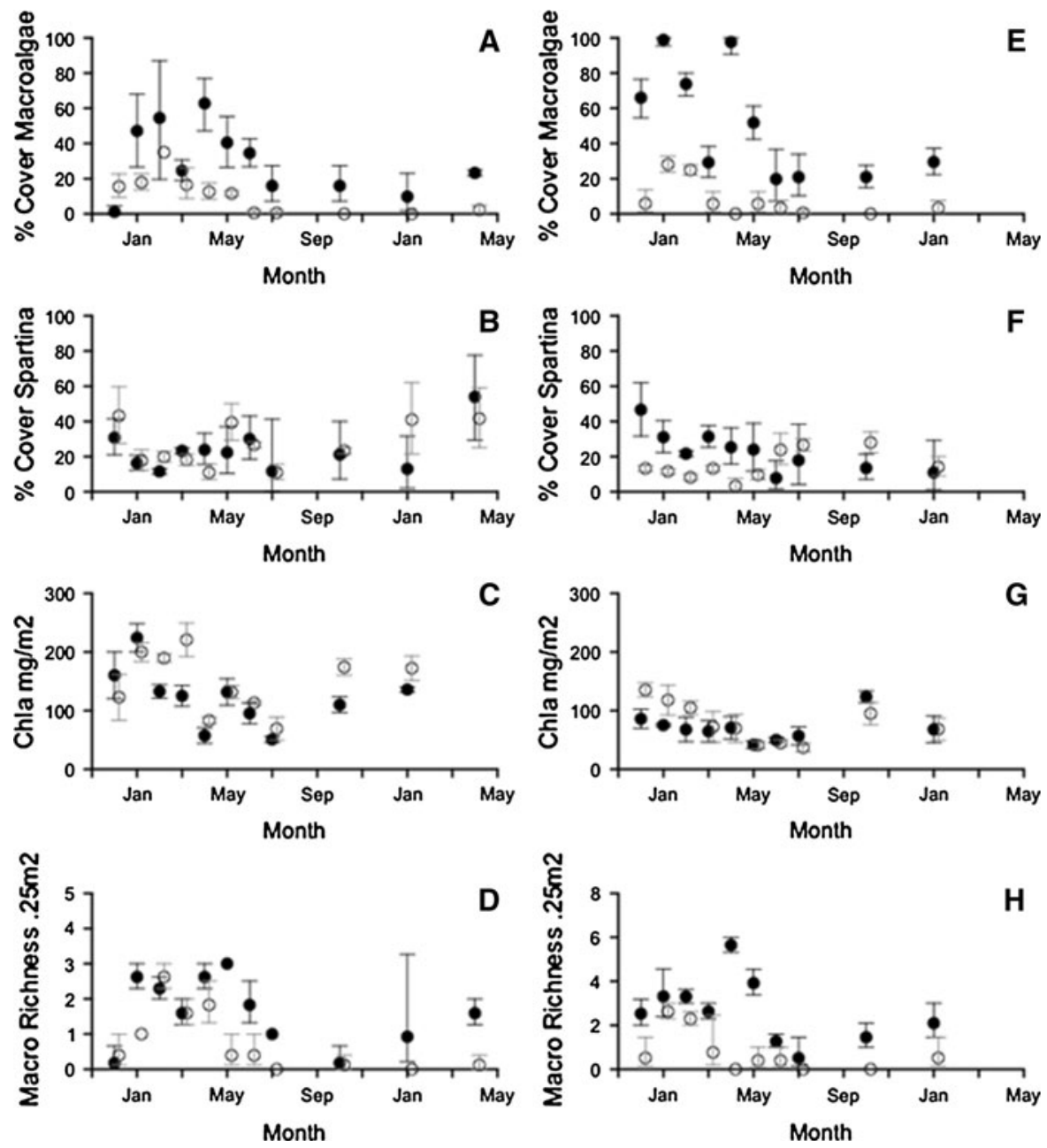
Table 2 Comparison of fixed and random factors in best models of algal and S. alterniflora patterns at silled and natural marshes over time

\begin{tabular}{|c|c|c|c|c|c|}
\hline \multirow[t]{2}{*}{ Response } & \multicolumn{2}{|c|}{$\begin{array}{l}\text { Fixed } \\
\text { effects }\end{array}$} & \multicolumn{3}{|c|}{ Random effects } \\
\hline & Sill & Date & Sill & Site & Transect \\
\hline Macroalgal cover & $X$ & & & & $X$ \\
\hline Macroalgal richness & $X$ & $\mathrm{X}$ & $X$ & $X$ & $X$ \\
\hline Microalgal abundance & $X$ & & $X$ & $\mathrm{X}$ & $X$ \\
\hline Spartina abundance & $X$ & & & & $\mathrm{X}$ \\
\hline Marco: micro abundance & $X$ & & & $X$ & $X$ \\
\hline Total benthic algal abundance & $\mathrm{X}$ & $\mathrm{X}$ & $X$ & $\mathrm{X}$ & $\mathrm{X}$ \\
\hline
\end{tabular}

Factors included in the best model as determined by $\mathrm{AIC}_{\mathrm{c}}$ are indicated with an ' $\mathrm{X}$ ', and full results from model comparisons are shown in Appendix A (see Electronic supplementary material)

(Table 2). This conclusion is based on the greater evidence in support of a model for macroalgal cover that did not require a time fixed effect or site random effect (Appendix B in Electronic supplementary material). The absolute abundance of macroalgae varied throughout the year, ranging from zero to $100 \%$ cover (Fig. 1).

At both natural sites, macroalgal richness was about twice that observed at silled sites (Table 3). At a finer (quadrat) scale, richness ranged from 0 to 6 taxa $/ 0.5 \mathrm{~m}^{2}$. Comparison of nested models including site, sill and date indicates that all three factors are necessary to model algal richness at the scale of $0.5 \mathrm{~m}^{2}$, though their effect sizes are small (Table 2; Appendix B in Electronic supplementary material). $\mathrm{AIC}_{\mathrm{c}}$ and evidence ratios indicate that both the full model and a model without a random effect for site are plausible, suggesting random site effects are of low importance in predicting algal richness at the quadrat scale in this dataset (Appendix B, Table B3 in Electronic supplementary material).

Microalgal abundance was correlated with site and sill, but not time (Table 2). Sills were associated with a reduced mean sediment chlorophyll $a$ concentration of $90.7 \mathrm{mg} / \mathrm{l}$ compared with $99.24 \mathrm{mg} / \mathrm{l}$ in natural marshes. Total benthic algal standing stock at silled sites was lower than at natural sites (mean \pm se: $174.08 \pm 62.15$ and $305.12 \pm 34.44 \mathrm{mg} / \mathrm{m}^{2}$, respectively). Benthic algal biomass also varied with time, and the magnitude of the sill effect varied among the two sites (Table 2; Fig. 1). However, the ratio of
Table 3 Macroalgal taxa observed at four sites including marshes with sills at Harker's Island-Restored (=silled) (HIR) and Pine Knoll Shores-Restored (PKSR) adjacent to marshes without sills at Harker's Island-Natural (HIN) and Pine Knoll Shores-(Natural PKSN)

\begin{tabular}{lllll}
\hline Taxon & HIN & HIR & PKSN & PKSR \\
\hline Total taxon richness & 16 & 8 & 13 & 6 \\
Agardhiella sp. & $\mathrm{X}$ & $\mathrm{X}$ & $\mathrm{X}$ & \\
Bryopsis sp. & $\mathrm{X}$ & $\mathrm{X}$ & $\mathrm{X}$ & $\mathrm{X}$ \\
Ceramium sp. & $\mathrm{X}$ & & & \\
Codium sp. & $\mathrm{X}$ & & & \\
Dasya baillouviana & $\mathrm{X}$ & & & \\
Dictyota sp. & $\mathrm{X}$ & & $\mathrm{X}$ & \\
Ectocarpus sp. & $\mathrm{X}$ & $\mathrm{X}$ & $\mathrm{X}$ & $\mathrm{X}$ \\
Enteromorpha sp. & $\mathrm{X}$ & $\mathrm{X}$ & $\mathrm{X}$ & $\mathrm{X}$ \\
Gracilaria folifera & $\mathrm{X}$ & & $\mathrm{X}$ & \\
Gracilaria tikvahiae & $\mathrm{X}$ & & $\mathrm{X}$ & \\
Gracilaria verrucosa & $\mathrm{X}$ & $\mathrm{X}$ & $\mathrm{X}$ & $\mathrm{X}$ \\
Hypnea musciformis & $\mathrm{X}$ & $\mathrm{X}$ & $\mathrm{X}$ & \\
Hypnea cervicornis & $\mathrm{X}$ & & & \\
Polysiphonia sp. & & $\mathrm{X}$ & & \\
Porphyra umbilicalis & & & $\mathrm{X}$ & $\mathrm{X}$ \\
Ulva sp. & $\mathrm{X}$ & $\mathrm{X}$ & $\mathrm{X}$ & $\mathrm{X}$ \\
Unknown branching red & $\mathrm{X}$ & & & \\
Unknown A & $\mathrm{X}$ & & $\mathrm{X}$ & \\
Unknown B & & & $\mathrm{X}$ & \\
\hline
\end{tabular}

macro: micro biomass was correlated with sills but not with time (Table 2).

S. alterniflora cover did not vary with time, and if there was an effect of sill it was weak and not dependent on site (Fig. 1; Appendix B in Electronic supplementary material). Two models were most plausible for $S$. alterniflora cover, and these were simply the mean of all Spartina cover across all samples and a model that allowed S. alterniflora cover to vary with sill as a random effect (Table B6).

\section{Experiment results}

Manipulations of macroalgal abundance had no effect on S. alterniflora density, height, growth or biomass (Table 4; Fig. 2). Absolute mean final S. alterniflora shoot density and height were unaltered by macroalgal abundance. Macroalgal abundance also did not influence changes in Spartina shoot density or height 
Table 4 Statistical results for tests of algal abundance treatments on Spartina growth and microalgal abundance (one-way ANOVA)

\begin{tabular}{lllll}
\hline Response & MS & df & $F$ & $P$ \\
\hline Change in density & 399.08 & 2 & 1.188 & 0.348 \\
Error & 335.86 & 9 & & \\
Proportion flowering & 19.184 & 2 & 0.132 & 0.878 \\
Error & 145.128 & 9 & & \\
Change in shoot height & 46.13 & 2 & 0.439 & 0.658 \\
Error & 105.00 & 9 & & \\
Above ground biomass & 5410.34 & 2 & 0.977 & 0.413 \\
Error & 5537.33 & 9 & & \\
Below ground biomass & 4.444 & 2 & 0.328 & 0.729 \\
Error & 13.568 & 9 & & \\
Shoot weight (total shoot & 1.653 & 2 & 1.300 & 0.320 \\
$\quad$ biomass/shoot density) & & & & \\
Error & 1.210 & 9 & & \\
Microalgal abundance & 252.0 & 2 & 0.136 & 0.875 \\
Error & 1859.1 & 9 & & \\
\hline
\end{tabular}

over the course of the growing season (Fig. 2a-b), or frequency of flowering on August 31st (Fig. 2c). Comparison of the open plots and procedural controls revealed no significant cage artifacts on $S$. alterniflora response variables (Table A1). Accordingly, analyses are presented for comparisons of addition, removal and control treatments (Table 4). Benthic microalgal abundance also did not vary with treatment (Fig. 2f; Table 4).
It is not likely that variation among plots obscured an effect of algae on S. alterniflora. Tidal elevation was the same for all treatments (one-way ANova: $\mathrm{MS}=1.473, F=0.639, P=0.604)$. Average initial macroalgal cover was $40.5 \%$ ( \pm se: $38.8-43.3 \%$ ) across all treatments before manipulation, and did not differ among treatments (one way ANOVA on arcsine square root transformed cover data: $\mathrm{MS}=0.014, F=0.359, P=0.559$ ).

Total benthic algal biomass was $125 \mathrm{mg} / \mathrm{m}^{2}$ in the removal treatments, comprising almost exclusively benthic microalgae. In algal addition treatments, total benthic algal biomass ranged from $171 \mathrm{mg} / \mathrm{m}^{2}$ in August to $428 \mathrm{mg} / \mathrm{m}^{2}$ in May. The ratio between treatments therefore ranged from far less than 1 in removal treatments to greater than 1 throughout much of the experiment for the addition treatments (Table 2).

\section{Discussion}

Benthic micro- and macro-algal primary producers are important in many estuaries and subtidal systems, contributing primary production, feeding herbivores and detritivores, regulating carbon and nutrient turnover and providing shelter (Roman et al. 1990; Sullivan and Moncreiff 1990; Wilson et al. 1990; Valiela et al. 1997; Piehler et al. 1998; Sundback and McGlathery 2005). Across our study sites, rock sills
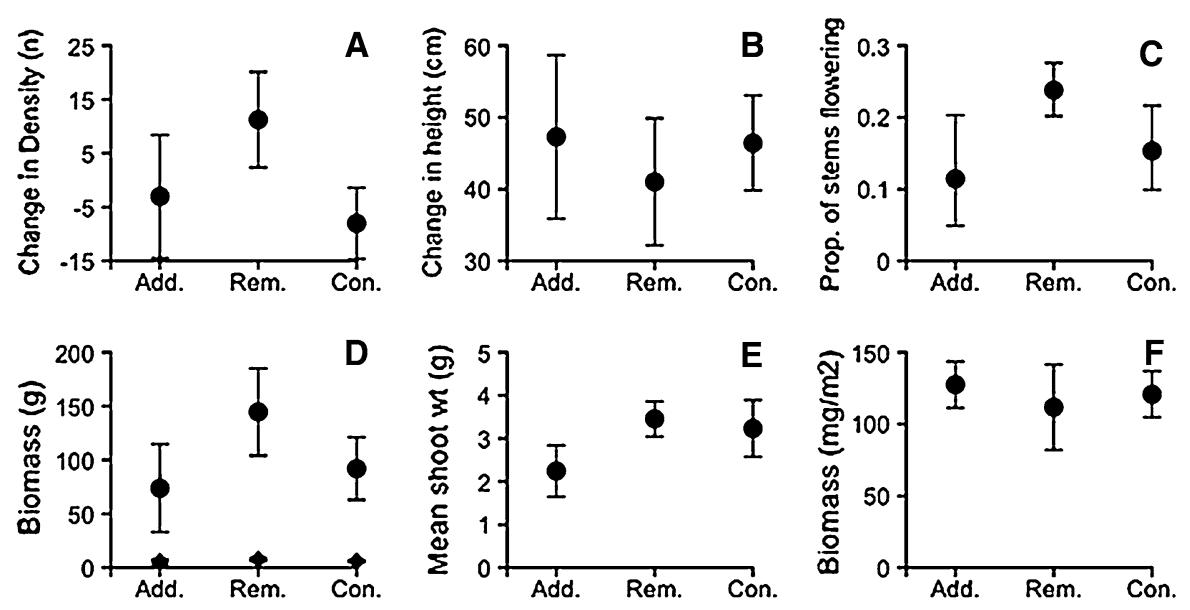

Fig. 2 Effects of an experimental manipulation of macroalgal cover on $S$. alterniflora mean ( $\pm \mathrm{se})$ a change in shoot density from Mar 17-Aug 31, b change in shoot height from Mar 17Aug 31, c proportion of stems flowering on Aug 31, d above (large symbols) and below (small symbols) ground biomass, e shoot weight and f microalgal (Chl a) biomass. Backtransformed means are presented for proportion of stems flowering. Statistical results in Table 4 
built to retain 'living shoreline' restoration projects are associated with reduced abundance of benthic algal primary producers at the low marsh edge (Table 2; Fig. 1). By changing the abundance of macroalgae in the low marsh zone, sills alter the composition and structure of primary producers in this ecologically important area. Potential consequences of decreasing the relative abundance of macroalgae include changes to the physical and trophic structure of the community and increasing total NPP and nutrient sequestration at the sediment surface (Sundback and McGlathery 2005).

We observed an effect of sills on macroalgal abundance in the low marsh that persisted throughout the year (Fig. 1; Table 2). Macroalgal abundance peaked in the late winter and again in late spring, and peak abundance at natural sites was as much as five times greater than at silled marsh edges. This difference meant that during summer and fall, macroalgae was absent at the silled sites but persisted at about $20 \%$ cover in the natural marshes. We detected clear patterns in algal abundance across silled and natural marshes in adjacent locations. The sills we studied had been installed for 7 (PKS) and 3 (HI) years, and these two sites had similar macroalgal abundance despite their difference in age and location (Fig. 1). This suggests that our observations are not due to recovery of the flora from the disturbance of the installation of the sill. The survey method alone, in the absence of experiments, cannot conclusively demonstrate that direct or indirect effects of sills are driving the differences in algal abundance. For example, we could not consider prior history of disturbance or other mechanisms as drivers of the algal patterns. Still, we are aware of no other differences between the sites and observed no other potential causes during our 12-month study.

Despite evidence of an effect of sills on benthic algal cover and richness, there was no effect of sills on the density, height or flowering of the most seaward S. alterniflora. In addition, our experiments did not reveal any indirect effects of sills on S. alterniflora mediated by algal abundance. We did not compare the absolute elevation or extent of S. alterniflora low marsh, so our metrics of $S$. alterniflora abundance are not an indicator of whether marshes are persisting, growing or shrinking over any time period outside the period of our study. It is quite likely that seaward marsh edges behind sills are at a higher elevation than natural marshes, and this elevation difference could be contributing to the differences in algal biomass. But because the experiment showed no effect of algal abundance on S. alterniflora growth, it is unlikely that this difference in algal abundance between silled and natural marshes affects low marsh growth in these two habitats.

The absence of an effect of benthic macroalgal abundance on S. alterniflora is somewhat unexpected. S. alterniflora growth is nutrient limited (Valiela and Teal 1974; Anderson and Treshow 1980; Osgood and Zieman 1993) and macroalgae may enhance S. alterniflora growth by naturally capturing water column nutrients and making them available to the sediments and growing marsh grass (Boyer and Fong 2005). The only experiment to test this hypothesis in the field found that Ascophyllum nodosum facilitated Spartina growth in Long Island Sound marshes (Gerard 1999). The potential for low marsh S. alterniflora to be nutrient limited in Bogue Sound suggested that macroalgae might facilitate marsh grass growth in Carolina marshes. However, an alternative explanation could be that in these eroding marsh edges, previously buried, nutrient rich sediments are being exposed and nutrient concentrations at the soil surface could be relatively high.

Restoration efforts that target foundation species can be an effective way to restore and maintain ecosystem function (Broome et al. 1988). After the establishment of a foundation species such as $S$. alterniflora in a restored site, many of the marsh biogeochemical and ecological functions achieve levels of function comparable to natural systems within a few years (Simenstad and Thom 1996; Piehler et al. 1998; Craft et al. 1999; Zheng et al. 2004). However, such rapid recovery is not always the case (Simenstad and Thom 1996; Zedler and Callaway 1999). While lower macroalgal abundance in 3-6 year old silled marshes in Bogue Sound could be consistent with a time lag of recovery from the implementation of the restoration project, the persistent reduced algal cover at silled marshes is more likely due to fundamental differences between silled and natural marshes including different physical structure and hydrodynamic regimes that deliver propagules, oxygen and nutrients to the low marsh zone. Additionally, the physical structure at sills could provide refuges for herbivores, and the absence of algae near sills during the summer and fall could reflect increased herbivory. 
Our results suggest that living shorelines alter the abundance of benthic algal primary producers. This is a new observation, indicating that the full impact of sill installation on subtidal and marsh communities is not understood. Benthic algae are important primary producers in North Carolina marshes, with a different ecological role than in other Atlantic coastal systems. For example, the low nutrient availability of Bogue Sound is not typical of estuarine conditions in other regions, suggesting that even marsh grass in the low zones could be limited by nitrogen availability. Further, in New England estuaries, macroalgal blooms resulting from nutrient enrichment can modify primary production and nutrient cycling (Valiela et al. 1997; Martins et al. 2007). These blooms do not occur in more southern coastal systems. Rather, low nutrient inputs and low residence time in coastal sounds like Bogue Sound lead to high water quality and a standing stock of benthic macro- and microalgae for most of the year (Kapraun and Zechman 1982). In addition, North Carolina marshes differ from marshes further to the south where the turbidity reduces light and limits benthic macroalgal production. In contrast to conditions in southern marshes and the bloom paradigm developed based on northern marshes, macroalgae in North Carolina are therefore relatively important primary producers, and reduction in its abundance could impact other trophic levels and nutrient cycling (Sullivan and Moncreiff 1990; Boyer and Fong 2005; Sundback and McGlathery 2005).

Shoreline stabilization projects are altering the composition, distribution and abundance of benthic primary producers at the seaward edge of salt marsh edges. Though significant change in benthic algal cover is likely important for many of the juvenile fish and invertebrates that use the salt marsh and sand flat habitats and for nutrient cycling, we did not detect an effect of sills or macroalgae on the density of cordgrass at the seaward edge of marshes. Therefore, we conclude that the effects of living shorelines on benthic algal primary producers at the seaward edge of salt marshes may not affect their maintenance of marsh foundation species.

Acknowledgments We are grateful to Sarah Lee, Michael Simpson, Suzanne Thompson, and Jon Violin for assistance in the field, and Elizabeth Wolkovich and Jim Regetz for help with analysis.
Open Access This article is distributed under the terms of the Creative Commons Attribution Noncommercial License which permits any noncommercial use, distribution, and reproduction in any medium, provided the original author(s) and source are credited.

\section{References}

Anderson CM, Treshow M (1980) A review of environmental and genetic factors that affect Spartina alterniflora height forms. Estuaries 3:168-176

Benoit J, Hardaway JCS, Hernandez D, Holman R, Koch E, McLellan N, Peterson S, Reed D, Suman D (2007) Mitigating shore erosion along sheltered coasts. National Research Council, Washington

Boyer KE, Fong P (2005) Macroalgal-mediated transfers of water column nitrogen to intertidal sediments and salt marsh plants. J Exp Mar Biol Ecol 321:59-69

Broome SW, Seneca ED, Woodhouse WW Jr (1988) Tidal salt marsh restoration. Aquat Bot 32:1-22

Burnham KP, Anderson DR (2002) Model selection and multimodel inference. Springer-Verlag, New York

CCSP (2009) Coastal sensitivity to sea-level rise: a focus on the mid-Atlantic region. In: Titus JG, Anderson KE, Cahoon DR, Gesch DB, Gill SK, Butierrez BT, Thieler ER, Williams SF (eds) U.S. Climate Change Science Program and the Subcommittee on Global Change Research. U.S. Environmental Protection Agency, Washington

Craft C, Reader J, Sacco JN, Broome SW (1999) Twenty-five years of ecosystem development of constructed Spartina alterniflora (Loisel) marshes. Ecol Appl 9:1405-1419

Currin CA, Delano PC, Valdes-Weaver LM (2008) Utilization of a citizen monitoring protocol to assess the structure and function of natural and stabilized fringing salt marshes in North Carolina. Wetl Ecol Manag 16:97-118

Dethier MN, Graham ES, Cohen S, Tear LM (1993) Visual versus random-point percent cover estimations: 'objective' is not always better. Mar Ecol Prog Ser 96:93-100

Donnelly JP, Bertness MD (2001) Rapid shoreward encroachment of salt marsh cordgrass in response to accelerated sealevel rise. Proc Natl Acad Sci USA 98:14218-14223

Gerard VA (1999) Positive interactions between cordgrass, Spartina alterniflora, and the brown alga, Ascophyllum nodosum ecad scorpioides, in a mid-Atlantic coast salt marsh. J Exp Mar Biol Ecol 239:157-164

Hauxwell J, McClelland J, Behr PJ, Valiela I (1998) Relative importance of grazing and nutrient controls of macroalgal biomass in three temperate shallow estuaries. Estuaries 21:347-360

Hershner C, Havens K, Mason P (2006) Living shorelines. In: Rivers and coasts. Center for Coastal Resources Management, Virginia Institute of Marine Sciences, College of William and Mary, Gloucester, pp 1-8

Kapraun DF, Zechman FW (1982) Seasonal and vertical zonation benthic marine algae on a North Carolina coastal jetty. Bull Mar Sci 32:702-714 
Martins I, Lopes RJ, Lillebo AI, Neto JM, Pardal MA, Ferreira JG, Marques JC (2007) Significant variations in the productivity of green macroalgae in a mesotidal estuary: implications to the nutrient loading of the system and the adjacent coastal area. Mar Pollut Bull 54:678-690

Micheli F, Bishop MJ, Peterson CH, Rivera J (2008) Alteration of seagrass species composition and function over two decades. Ecol Monogr 78:225-244

Nixon SW (1980) Between coastal marshes and coastal waters-a review of twenty years of speculation and research on the role of salt marshes in estuarine productivity and water chemistry. In: Hamilton P, MacDonald KB (eds) Estuarine and Wetland Processes. Plenum, New York, pp 437-525

O'Connor MI, Piehler MF, Leech DM, Anton A, Bruno JF (2009) Warming and resource availability shift food web structure and metabolism. PLoS Biol 7(8):e1000178

Osgood DT, Zieman JC (1993) Factors controlling aboveground Spartina alterniflora (smooth cordgrass) tissue element composition and production in different-age barrier-island marshes. Estuaries 16:815-826

Piehler MF, Currin CA, Cassanova R, Paerl HW (1998) Development and N-2-fixing activity of the benthic microbial community in transplanted Spartina alterniflora marshes in North Carolina. Restor Ecol 6:290-296

Roman CT, Able KW, Lazzari MA, Heck KL (1990) Primary productivity of angiosperm and macroalgae dominated habitats in a New-England salt-marsh-a comparativeanalysis. Estuar Coast Shelf Sci 30:35-45

Simenstad CA, Thom RM (1996) Functional equivalency trajectories of the restored Gog-Le-Hi-Te estuarine wetland. Ecol Appl 6:38-56
Sullivan MJ, Moncreiff CA (1990) Edaphic algae are an important component of salt-marsh food-webs-evidence from multiple stable isotope analyses. Mar Ecol Prog Ser 62:149-159

Sundback K, McGlathery K (2005) Interactions between benthic macroalgal and microalgal mats. In: Kristensen E, Haese RR, Kostka JE (eds) Interactions between macroand microorganisms in marine sediments. American Geophysical Union, Washington

Valiela I, Teal JM (1974) The nitrogen budget of a salt marsh ecosystem. Nature 280:652-656

Valiela I, McClelland J, Hauxwell J, Behr PJ, Hersh D, Foreman K (1997) Macroalgal blooms in shallow estuaries: controls and ecophysiological and ecosystem consequences. Limnol Oceanogr 42:1105-1118

Warren RS, Niering WA (1993) Vegetation change on a northeast tidal marsh: interaction of sea-level rise and marsh accretion. Ecology 74:96-103

Wilson KA, Able KW, Heck KL (1990) Predation rates on juvenile blue crabs in estuarine nursery habitats-evidence for the importance of macroalgae (Ulva lactuca). Mar Ecol Prog Ser 58:243-251

Zedler JB, Callaway JC (1999) Tracking wetland restoration: do mitigation sites follow desired trajectories? Restor Ecol 7:69-73

Zheng L, Stevenson RJ, Craft C (2004) Changes in benthic algal attributes during salt marsh restoration. Wetlands 24:309-323 